\title{
THE SHACKLES OF POVERTY OF THE FARMERS IN THE ISOLATED AND VULNERABLE COMMUNITY
}

\author{
Hatu Dewinta Rizky R.*, Wisadhirana Darsono, Susilo Edi \\ Master's Program in Social Sciences, Faculty of Social and Political Sciences, \\ University of Brawijaya, Indonesia \\ *E-mail: dewintaarizky@gmail.com
}

\begin{abstract}
This study refutes Putnam's statement that people prefer to deal with people they know and can produce results in realizing their goals (Field, 2010, p. 3). Although the farmers in the Isolated and Vulnerable Community (Komunitas Adat Terpencil/KAT) do not only deal with people they know in the networking process, it seems that they are still unable to break the shackles of poverty. This study uses Putnam's social capital theory. The study utilizes a qualitative method with a case study approach. Data collection techniques were observation, interviews, and documentation. In-depth interviews were conducted with six informants selected through the snowball sampling technique. The results of the study show that the farmers in the Isolated and Vulnerable Community apply the bridging and linking strategies to support their farm. These strategies help the community to get capital only but do not help the community to break the shackles of poverty because of exploitation. In addition, the government seems unable to help the community because the capital they have is below the middlemen.
\end{abstract}

\section{KEY WORDS}

Farmers, poverty, middlemen, public service.

The issue of poverty seems to be a social phenomena problem, especially in developing countries like Indonesia. Indonesia certainly manages long-term and short-term development. Long-term development has produced the rate of economic growth by an average of 7 percent per year. The development process went smoothly until the 1970s and 1980s. However, Indonesia's economic development has also experienced external shocks several times, such as the falling prices of crude oil on the international market. These conditions cause several problems, one of which is poverty (Prawoto, 2005).

Based on data from Statistics Indonesia, the number of poor people in Indonesia was recorded at 29.89 million people (12.36 percent) in September 2011. The percentage of poor people in urban areas was 9.23 percent and the poor people in rural areas was 15.72 percent in March 2011, down slightly to 15.59 percent in September 2011 (Statistics Indonesia, 2012). The number of poor people in Gorontalo Province as the research location was 198.51 thousand people (16.81\%) in 2018.

The authors perceive that the current State's development strategy tend to focus on economic growth, even though the community actually need many things. State progress is not only measured by economic growth but also other aspects such as health, education, and public life insurance. The development strategy appears not to be followed by income distribution for all segments of society. Many programs are only top down, causing downward distribution does not occur, especially in the isolated and vulnerable community.

The Isolated and Vulnerable Community (Komunitas Adat Terpencil/KAT) is still underdeveloped in the social, political, and economic sectors. The Isolated and Vulnerable Community in Buhu Village, Gorontalo Regency is still unable to break the shackles of poverty. Based on the profile data of Buhu Village, the largest number of poor people is in Durian Hamlet of 114 families with 58 families as the Isolated and Vulnerable Community. All members of the Isolated and Vulnerable Community in Durian Hamlet make a living as farmers. 
Scott in (Prawoto, 2009) states that poverty causes villagers to be willing to sacrifice anything to have safety life, to risk physical labor to produce profits for local middlemen, and to receive wages not commensurate with the costs spent. These conditions also happen in the Isolated and Vulnerable Community in Durian Hamlet. However, the relationship between the farmers and the middlemen seems to help the farmers to maintain their farming activities even though they seem to be 'exploited' by the middlemen. Edi Susilo $(2018$, p. 2) states that the patron-client in fishing community is a social capital, which should be used as a base to help them out of poverty. This study aims to investigate the strategies used by the Isolated and Vulnerable Community in Durian Hamlet to survive amid their poverty. This study aims to understand the bridging pattern and linking potential in the Isolated and Vulnerable Community in running their farm.

\section{LITERATURE REVIEW}

This research uses Putnam's social capital theory. Putnam provides three typologies of social capital. Bonding social capital is a type of social capital in the context of inward-looking ideas, relations, and attention. This type of social capital generally appears in a homogeneous society. Unlike bonding, bridging social capital is inclusive and outwardlooking. The bridging form of social capital is also called the modern form of a group, association or community. Bridging social capital leads to the joint answer search to solve group problems by utilizing networks owned by individuals in groups. Linking social capital is a social relationship characterized by the relationships between several levels of social strength or social status in society (Hasbullah, 2006).

\section{METHODS OF RESEARCH}

This study uses a qualitative method with a case study approach. Data collection techniques were observation, interviews, and documentation. In-depth interviews were conducted with six informants selected through the snowball sampling technique. The researchers determined the Village Head as the key informant and the main informant. The Village Head explained the general conditions and provided names that could be used as the informants in this study. The data obtained were analyzed using a pattern-matching technique. The study was conducted in Durian Hamlet, Buhu Village, Tibawa District, Gorontalo Regency, Gorontalo Province.

\section{RESULTS AND DISCUSSION}

The dependency of the farmers on the middlemen. The agricultural sector has an important role in labor absorption in rural areas as can be seen that most rural community work in the agricultural sector. It is in line with the data which shows that the main livelihoods of the villagers in Buhu Village, Tibawa District, Gorontalo Regency are mostly as farmers or corn farmers. In 2015, the highest livelihoods of the villagers in Buhu Village was in the agricultural sector which amounted to 408 people.

The farmers of the Isolated and Vulnerable Community cannot be separated from the middlemen in running their farms. The Isolated and Vulnerable Community in Durian Hamlet rely heavily on agricultural products as their source of life. Their undeveloped economic conditions certainly provide additional problems for the farmers, i.e. the cost constraints. They need capital to run the farm and buy seeds and fertilizers. Consequently, they choose to borrow money from the middlemen to be used as capital in running their farm.

The Isolated and Vulnerable Community in Durian Hamlet rely heavily on agricultural products as their source of life. Sometimes, the farmers experience distress when the harvest is unsatisfactory. It can be seen that the farmers also rely on loan capital from the middlemen. High monthly expenditure and low income make people choose to go into debt.

The researchers observed that some problems occur when people's income is very dependent on agricultural products. Unsatisfactory harvests lead to a small income. 
According to Gustiyana (2003), farm income can be divided into agriculture income and household income. Revenue represents a reduction of revenues with total costs. Household income is income derived from farming activities coupled with the income derived from activities outside the farming activities. Agriculture income is different from gross income (output) and the cost of production (input) which is calculated per month, per year, and per planting season. Non-agriculture income is the income earned as a result of activities outside the farming activities such as trade, motorcycle taxi, and so on. Most people in the Isolated and Vulnerable Community work as farmers only.

Borrowing capital from the middlemen is not fully profitable for the farmers. The middlemen seem to not help the farmers. They establish a relationship with small farmers merely based on economic relationship. The middlemen only take as much profit as possible from the agricultural products of the farmers in the Isolated and Vulnerable Community in Durian Hamlet. Through the field data, the informants acknowledged that the farmers are given a $20 \%$ loan interest when borrowing the capital. The middlemen also buy the farmers' agricultural products at low prices such as paying 2300 while the normal price is 2500 .

Basically, the farmers in the Isolated and Vulnerable Community are small farmers and have a high dependency on the middlemen. They feel helped because the middlemen provide the farmers' needs such as capital need. The middlemen will lend capital with interest to the farmers. Furthermore, the middlemen purchase the farmer's harvests at low prices far below the market price and sell them at market prices to make a big profit. The middlemen also become investors for the farmers. Thus, the relationship between the small farmers and the middlemen known as a patron-client relationship is formed. The middlemen certainly play a role in providing help to the farmers as their clients. However, when the farmers in the Isolated and Vulnerable Community harvest, the agricultural products must be sold to the middlemen at low prices far below the market price. The middlemen will seek maximum profits and certainly harm the farmers. As the result, the farmers in the Isolated and Vulnerable Community could not break the shackles of poverty.

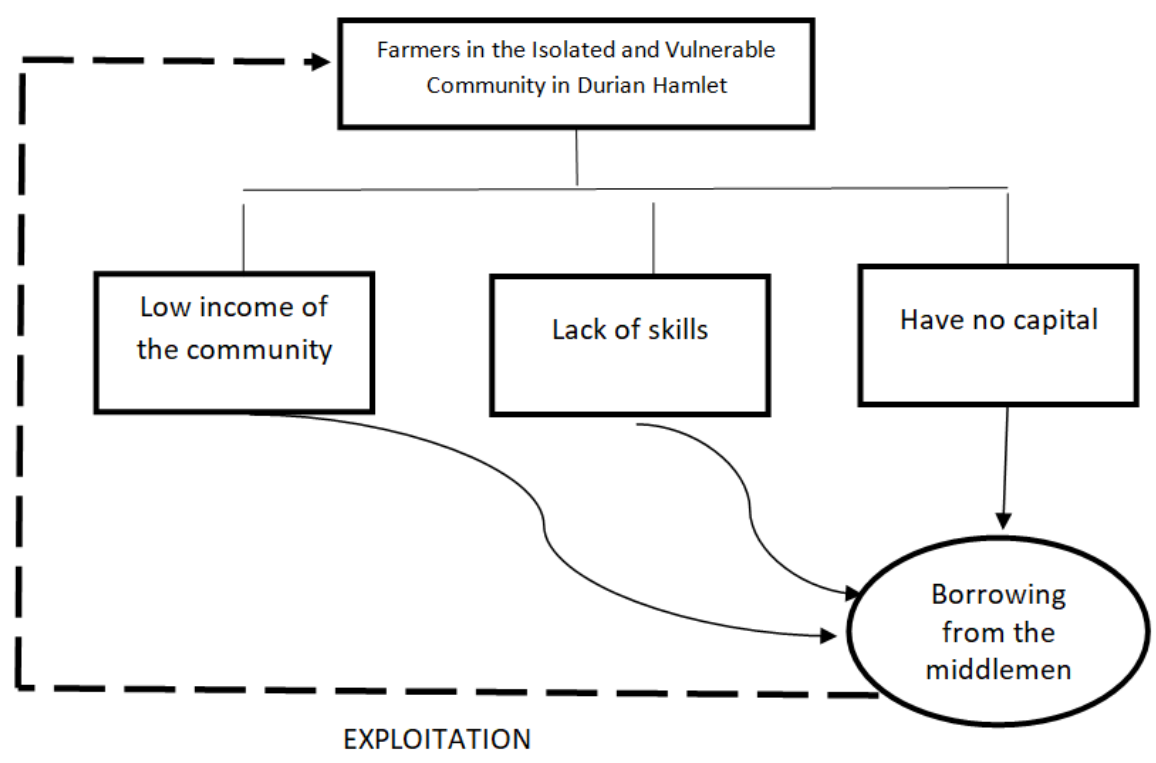

Figure 1 - The relationship between the farmers in the Isolated and Vulnerable Community and the middlemen

From the field data, the researcher draws the proposition on the dependency of the farmers on the middlemen seems to be sustainable and certainly harm the farmers. If this relationship is continuously established, unnoticed by the farmers, the middlemen conduct economic exploitation to the farmers. Because the middlemen feel that they already help the farmers, they feel entitled to use their power over farmers to gain a profit. Thus, the farmers 
are indirectly exploited at the present and have no choice but to build a network with the middlemen.

Bridging and linking strategies by the Isolated and Vulnerable Community. A little can be done by the Isolated and Vulnerable Community to break the shackles of poverty. Low education level and lack of skills make them difficult to improve their economy. Moreover, the Isolated and Vulnerable Community seem isolated, reluctant to improve their standard of living, seem to give in, and work only to fulfill their daily needs. However, the facts in the field are different. The Isolated and Vulnerable Community is able to connect with other people by conducting the networking process with people outside their community. It is different from Putnam's statement that people prefer to deal with people they know and can produce results in realizing their goals (Field, 2010, p. 3). The facts in the field show that the Isolated and Vulnerable Community do not only deal with people they know in making cooperation.

Bridging social capital as one of the strengths and energies of social capital is the ability to bridge or connect relationships between individuals and groups with different original identity. The Isolated and Vulnerable Community opens opportunities to communicate and connect with people outside the community. This is supported by their current residence which has easier access to interact with people outside their community. Many factors require them to connect with people outside their community for their interests, one of which is for agriculture.

The Isolated and Vulnerable Community does not only interacts communicatively with people outside their community but also interact in the form of cooperation, i.e. the networking process. According to Hasbullah (2006, p. 30), outward-looking groups' attitudes make it possible to establish mutually beneficial networks with associations or groups outside their groups. Progress will be more easily achieved because idea transfer and exchange develop continuously and stimulate group and individual development.

The Isolated and Vulnerable Community exchanges with outside parties in the form of cooperation. They borrow money from the middlemen for their agricultural capital. On the other side, the middlemen take the maximum profit from the Isolated and Vulnerable Community by giving them loan interest and buying harvests at cheap prices. As long as the process is felt to be 'equally' profitable, the cooperation process will continue. The established relationship is based on the interests for mutual benefit because of potential differences and variations of each group. The farmers actually do not get a real benefit. The farmers have no choice and the quickest way to get capital is to borrow from the middlemen.

When the farmers do not develop a relationship with people outside their community, they will certainly have difficulties. They cannot just rely on their internal potential. Therefore, it is necessary and very important to build outside relationship to optimize their potential and to open potential opportunities existing outside their community. Bridging social capital is the relevant strength to be developed because they need to interact with the outside community. So, the Isolated and Vulnerable Community do the networking process by asking for help from people outside their community, i.e. the middlemen to borrow capital. Actually, the networking process through bridging social capital is very helpful for the farmers to get capital aid and market their agricultural products. However, this relationship does not help the farmers to break the shackles of poverty.

In addition to bridging social capital, the community also conducts linking social capital. Linking social capital is a social relationship characterized by the relationships between several levels of social strength or social status in society. As previously explained, a homogeneous group will hinder the creative relationship with the State and other groups as well as obstruct overall community development. The researchers obtained different results from the field. Although the Isolated and Vulnerable Community is very homogeneous and has strong bonding, it accepts changes and has a good and intense relationship with the government.

Relationship with the village government is a vertical hierarchy. Thus, the networks and relationships are important to be expanded as the community's dynamic effort to overcome their problems. According to field data, the village government is aware that the farmers in the village are being exploited by the middlemen. The Village Government has tried to 
intervene through Village Enterprises (Badan Usaha Milik Desa, BUMDES) but the results are not maximal because the amount of capital is still below the middlemen who already have billions of capital. In this case, the village government already give special attention, but the results will be less optimal with no supporting institutions such as financial institutions and cooperatives. The access of the community should be facilitated as well when such institutions exist. Thus, the farmers in the Isolated and Vulnerable Community have no choice but to borrow from the middlemen.

\section{CONCLUSION}

The researcher draws the proposition on the dependency of the farmers on the middlemen seems to be sustainable and certainly harm the farmers. If this relationship is continuously established, unnoticed by the farmers, the middlemen conduct economic exploitation to the farmers. Because the middlemen feel that they already help the farmers, they feel entitled to use their power over farmers to gain a profit. Thus, the farmers are indirectly exploited at the present and have no choice but to build a network with the middlemen.

The farmers in the Isolated and Vulnerable Community already conduct the bridging and linking strategies to support their farm. The Isolated and Vulnerable Community is able to connect with other people by conducting the networking process with people outside their community. It is different from Putnam's statement that people prefer to deal with people they know and can produce results in realizing their goals (Field, 2010, p. 3). The facts in the field show that the Isolated and Vulnerable Community do not only deal with people they know in making cooperation. However, this does not seem to be able to help people to break the shackles of poverty.

The bridging strategy is realized by conducting the networking process with the middlemen. The cooperation process with the middlemen seems to be their only choice. The poor condition of the farmers with no capital becomes the factor they conduct the networking process with the middlemen. Although the farmers gain no benefit from the loan interest and the cheap purchase price, it becomes very helpful because they need capital from the middlemen to run their farm. In addition, the linking strategy is also performed by having a good relationship with the village government. The village government already give special attention, but the results will be less optimal with no supporting institutions such as financial institutions and cooperatives. The access of the community should be facilitated as well when such institutions exist. Thus, the farmers in the Isolated and Vulnerable Community(IPV) have no choice but to borrow from the middlemen and unable to break the shackles of poverty.

\section{REFERENCES}

1. Field, J. (2010). (Nurhadi, Trans.) Bantul: Kreasi Wacana.

2. Gustiyana, H. (2003). Analisis Pendapatan Usahatani Untuk Produk Pertanian. Jakarta: Selemba Empat.

3. Hasbullah , J. (2006). Social Capital (Menuju Keunggulan Budaya Manusia Indonesia). Jakarta: MR-United.

4. Hasbullah, J. (2006). Social Capital (Manuju Keunggulan Budaya Manusia Indonesia). Jakarta: MR-United.

5. Prawoto, N. (2009). Memahami Kemiskinan and Strategi Penanggulangannya Vol. 9 No.1. Jurnal Ekonomi and Studi Pembangunan , 56-68.

6. Statistik, B. P. (2012). Profil Kemiskinan Di Indonesia Spetember 2011. Jakarta: Badan Pusat Statistik.

7. Susilo, E. (2018). Fisherman's Social Capital Marginalized: (Keeping the Social Sustainability Fisheries Development). Malang: University of Brawijaya. 